\title{
Maritime Weather Prediction Using Fuzzy Logic in Ternate Waters North Maluku
}

\author{
Anisa Sangadji ${ }^{1}$, Aulia Siti Aisjah ${ }^{2}$, and Gunawan Nugroho ${ }^{3}$
}

\begin{abstract}
Ternate waters of North Maluku is one of Indonesian eastern waters whose maritime weather is often unpredictable. Weathers prediction is important to avoid accidents in the waters. The aim of this research is to obtain a predictor model of wave's height and current's speed suitable for the Ternate waters using Takagi-Sugeno fuzzy logic. The data used is data from BMKG Maritime of Bitung which recorded per 6 hours during 5 years from July 2010 - June 2015. In order to reach accuracy of $>85 \%, 3$ model predictor's that used waves height and current speed are predictor Model A, Model B and Model C. Each model uses different input and total membership function. The result of this research shows that the Model $\mathrm{C}$ is the best model for Ternate waters. Model $\mathrm{C}$ uses 4 membership functions for 3 input variables. Inputs of waves height predictor consist of the actual wind speed $(U(t))$, actual waves height $(H(t))$ and waves height 6 hours ago $(H(t-6))$ and accuracy percentage of waves height 6 hours ahead $(H(t+6))$ is 91,99\%; while inputs of current speed predictor consist of actual wind speed $(\mathrm{U}(\mathrm{t}))$, actual current speed $(\mathrm{Cu}(\mathrm{t}))$ and current speed 6 hours ago $(\mathrm{Cu}(\mathrm{t}-6))$ and accuracy percentage of current speed 6 hours ahead $(\mathrm{Cu}(\mathrm{t}+6))$ is $81,63 \%$.
\end{abstract}

Keywords - Maritime weather, waves height, current speed, Takagi-Sugeno fuzzy logic, Ternate waters, accuracy.

\begin{abstract}
Abstrak - Perairan Ternate Maluku Utara merupakan salah satu perairan di kawasan timur Indonesia yang cuaca maritimnya sering tidak menentu. Hal ini menyebabkan potensi terjadinya kecelakaan laut sangat besar. Penelitian ini bertujuan untuk memperoleh model prediktor ketinggian gelombang and kecepatan arus laut terbaik di Perairan Ternate dengan menggunakan logika fuzzy Takagi-Sugeno. Data yang digunakan adalah data BMKG Maritim Bitung yang direkam per 6 jam selama 5 tahun dari Juli 2010 - Juni 2015. Untuk mendapatkan akurasi > 85\% digunakan 3 model perancangan prediktor yaitu prediktor ketinggian gelombang and kecepatan arus Model A, Model B and Model C. Setiap model menggunakan masukan and jumlah fungsi keanggotaan yang berbeda-beda. Hasil penelitian menunjukkan Model $\mathrm{C}$ adalah model terbaik di Perairan Ternate, dimana prediktor ini menggunakan 4 fungsi keanggotaan untuk 3 variabel masukan. Masukan pada prediktor ketinggian gelombang terdiri dari kecepatan angin aktual (U(t)), ketinggian gelombang aktual $(H(t))$ and ketinggian gelombang 6 jam sebelumnya $(H(t-6))$ and memilki prosentase akurasi pada prediksi ketinggian gelombang 6 jam ke depan yaitu 91,99\%; seandgkan masukan pada prediktor kecepatan arus terdiri dari kecepatan angin aktual $(\mathrm{U}(\mathrm{t}))$, kecepatan arus aktual $(\mathrm{Cu}(\mathrm{t}))$ and kecepatan arus 6 jam sebelumnya $(\mathrm{Cu}(\mathrm{t}-6))$ and memiliki prosentase akurasi pada prediksi kecepatan arus 6 jam ke depan yaitu $86,33 \%$.
\end{abstract}

Kata Kunci-Cuaca Maritim, Ketinggian Gelombang, Kecepatan Arus, Logika Fuzzy Takagi-Sugeno, Perairan Ternate, Akurasi.

\section{INTRODUCTION}

U npredictable maritime weathers can interfere sea transportation especially the ship sailings. Many research to find weathers prediction methods to provide quick, accurate and all-covered informations are done recently. BMKG is national department that has responsibility as weathers observer and to predict weathers by conventional method (statistic or dynamic methods) with 5-10 km coverage for 1 observation point at the predictable area [1].

Maritime weathers prediction activities have been done with many modeling techniques and several applied methods from the simplest to the complex methods [2].

Maritime weathers prediction in the sailings strips using fuzzy logic are done continual to reach high accuracy. The accuracy of a predictor model is influenced by input variables [3].

The strategies of parameter selection on Fuzzy Logic Systems will provide the forecast that is easily understood by the fishermen and sea transport users [4].

Ternate waters of North Maluku is one of Indonesian eastern waters whose maritime weather is often

${ }^{1}$ Anisa Sangadji, Aulia Siti Aisjah, and Gunawan Nugroho are with Departement of Physics Engineering, Faculty of Industrial Technology, Institut Teknologi Sepuluh Nopember, Surabaya, 60111, Indonesia. Email: anisasangadji@gmail.com; auliasa@ep.its.ac.id gunawan@ep.its.ac.id unpredictable and there is no research has been done therefore this research aims to get the best predictor model. The problem in this research is how to obtain a predictor model of wave height and current speed of the best in Ternate waters using Takagi-Sugeno fuzzy logic.

\section{METHODS}

Fuzzy logic is used for prediction system. Data that used for this paper is daily data from (BMKG) Maritim Bitung which recorded per 6 hours during 5 years from July 2010 to June 2015. Data is divided into $80 \%$ training data and $20 \%$ validation data [2]. Data collection location can be shown by Fig. 1 .

In the modeling process 3 waves height and current speed models consist of Model A, Model B, and Model $\mathrm{C}$ are used to reach fuzzy system accuracy $>85 \%$. The training process is using $80 \%$ data is 6580 data (July 2010-December 2014).

In the fuzzification process, membership function determination is done after wind speed, wave height and current speed data classified using Fuzzy Cluster Mean (FCM). FCM has function to determine minimum, maximum and mean value to be entered into FIS system. Rule base is using IF-THEN and connected with operation logic AND because all rules depends and impacts each others [5]. 


\section{A. Waves Height and Current Speed Predictor Model A \\ 1) Waves Height Predictor}

This model is using 3 input variables, 1 output and 49 rules base. Input consists of actual wind speed $(\mathrm{U}(\mathrm{t}))$, actual waves height $(\mathrm{H}(\mathrm{t}))$ and waves height 6 hours ago $((\mathrm{H}(\mathrm{t}-6))$. This is can be shown by Fig. 2 .

This model is using 7 membership functions with 7 categories, for wind speed consists of Calm, Light Air, Light Breeze, Gentle Breeze, Moderate Breeze, Freeze Breeze and Strong Breeze; waves height consists of Glassy, Rippled, Wavelets, Slight, Moderate, Rough and Very Rough. This is can be shown by Fig. 3-4 and waves height rule base algorithm are can be shown by Table 1 .

\section{2) Current Speed Predictor}

This model is using 3 input variables, 1 output and 49 rules base. Input consists of actual wind speed $(\mathrm{U}(\mathrm{t}))$, actual current speed $(\mathrm{Cu}(\mathrm{t}))$ and current speed 6 hours ago $((\mathrm{Cu}(\mathrm{t}-6))$. This is can be shown by Fig. 5 .

This model is using 7 membership functions with 7 categories, for wind speed consists of Calm, Light Air, Light Breeze, Gentle Breeze, Moderate Breeze, Freeze Breeze and Strong Breeze; current speed consists of Very Slow, Slow, Smooth, Slight, Average, Fast and Very Fast. This is can be shown by Fig. 6-7 and current speed rule base algorithm are can be shown by Table 2 .

B. Waves Height and Current Speed Predictor Model B

\section{1) Waves Height Predictor}

This model is using 4 input variables, 1 output and 25 rules base. Input consists of actual wind speed $(\mathrm{U}(\mathrm{t}))$, wind speed 6 hours ago (U(t-6)), actual waves height $(\mathrm{H}(\mathrm{t}))$ and waves height 6 hours ago $((\mathrm{H}(\mathrm{t}-6))$. This is can be shown by Fig. 8 .

In FIS editor there are 5 membership functions with 5 catagories each input for wind speed consists of Calm, Light Air, Light Breeze, Gentle Breeze and Moderate Breeze; waves height consist of Glassy, Rippled, Wavelets, Slight and Moderate. This is can be shown by Fig. 9-10 and current speed rule base algorithm are can be shown by Table 4 .

\section{2) Current Speed Predictor}

This model of Current speed FIS editor consist of 4 input variables, 1 output and 25 rules base. Input consists of actual wind speed $(\mathrm{U}(\mathrm{t}))$, wind speed 6 hours ago $(\mathrm{U}(\mathrm{t}-6))$, actual current speed $(\mathrm{Cu}(\mathrm{t}))$ and current speed 6 hours ago $(\mathrm{Cu}(\mathrm{t}-6))$. This model is using 5 membership functions with 5 categories, for wind speed consists of Calm, Light Air, Light Breeze, Gentle Breeze and Moderate Breeze; current speed consists of Very Slow, Slow, Smooth, Slight and Average. This is can be shown by fig. 11, membership function and current speed rule base algorithm are can be shown by fig. 12-13 and Table 3.

C. Waves Height and Current Speed Predictor Model C

This model is using 3 input variables, 1 similar output with model $A$ and 16 rule bases. In FIS editor there are 4 membership functions with 4 catagories each input for wind speed consists of Calm, Light Air, Light Breeze, Gentle Breeze; waves height consist of Glassy, Rippled, Wavelets and Slight; current speed consists of Very Slow, Slow, Smooth and Slight. This is can be shown by fig. 14 and fig. 17. Membership function are can be shown by fig. 15-19, and current speed and wave height rule base algorithm are can be shown by Table 5-6.

\section{RESULTS AND DISCUSSIONS}

Validation data to validate the Model A, Model B, Model C predictor as 724 data in January-June 2015. Prediction accuracy is affected by input variable [3]. Gaussian membership function is used in the fuzzification process because it has smooth factor and no zero value in each point [5].

A. Waves Height Predictor Result

In Model A waves height predictor, percentage of validation results for the prediction of 6 hours, 12 hours, 18 hours and 24 hours ahead respectively is $18.92 \%$; $23.20 \%$; $23.89 \%$ and $23.48 \%$. Biggest percentage is waves height prediction for the next 18 hours as 23,89 $\%$. Fig. 20 shows consideration between prediction result (red) and actual result of BMKG (blue). $\mathrm{X}$ axis is amount of data while y axis is wave height $(\mathrm{m})$. Graph prediction of wave height 18 hours ahead $(\mathrm{H}(\mathrm{t}+6))$ Model A has not followed the pattern graph of waves height actual, this is because of the use 7 membership functions based on division of the Beaufort scale causes narrowing width of Gaussian function, so most of the data is not there membership function properly. Data which has the same membership function only found in two categories namely is wavelet $(1.04 \mathrm{~m}-1.33 \mathrm{~m})$ and slight $(1.34 \mathrm{~m}$ $1.65 \mathrm{~m})$. This is can be shown by Fig. 20.

At the Model B waves height Predictor, percentage of validation results for the prediction of 6 hours, 12 hours, 18 hours and 24 hours ahead respectively is $59.81 \%$; $55.25 \%$; $54.69 \%$ and $57.32 \%$. In Figure 22 shows that most small graph patterns predicted outcomes may follow the graph pattern of the actual waves height, this means that some data have similarities in membership functions. In this model, the largest percentage of the predictions contained in waves height 6 hours ahead is $59.81 \%$. This happens because the 5 membership functions used by the division of the Beaufort scale all but two categories represented a more dominant at that rippled $(0,96 \mathrm{~m}-1,35 \mathrm{~m})$ and wavelet $(1,36 \mathrm{~m}-1,78$ $\mathrm{m})$.

In Model $\mathrm{C}$ waves height predictor, percentage of validation results for the prediction of 6 hours, 12 hours, 18 hours and 24 hours ahead respectively is $91.99 \%$; $86.46 \%$; $85.22 \%$ and $86.34 \%$. In Figure $24-27$ is seen that the predicted graph results wave height 6 hours ahead $(\mathrm{H}(\mathrm{t}+6))$ Model $\mathrm{C}$ can largely follows the pattern graph of the actual waves height. This means that most of the data are similar in membership functions. This happens because the 4 membership functions used by division of the Beaufort scale, all represented and 3 categories more dominant is glassy $(0.33 \mathrm{~m}-1.06 \mathrm{~m})$, rippled $(1.07 \mathrm{~m}-1.55 \mathrm{~m})$ and wavelet $(1.56 \mathrm{~m}-2.12 \mathrm{~m})$. The largest percentage of the predictions contained in waves height 6 hours ahead is $91.99 \%$.

\section{B. Current Speed Predictor Result}

In Model A current speed predictor, percentage of validation results for the prediction of 6 hours, 12 hours, 18 hours and 24 hours ahead respectively is $43.51 \%$; $39.50 \% ; 38.95 \%$ and $44.89 \%$. Figure 21 is a graph of the results predicted and actual current speed 24 hours ahead $(\mathrm{Cu}(\mathrm{t}+24))$ Model A with a percentage of $44.89 \%$, Prediction graph patterns fraction follows the pattern graph of the actual current speed, this means that a small portion of data has a similarity in membership functions. This happens because the 7 membership functions used 
by the division of the Beaufort scale only two categories that have in common is very slow $(0.08 \mathrm{~cm} / \mathrm{s}-5.55$ $\mathrm{cm} / \mathrm{s})$ and a fraction slow $(5.56 \mathrm{~cm} / \mathrm{s}-10,27 \mathrm{~cm} / \mathrm{s})$.

At the Model B current speed predictor, percentage of validation results for the prediction of 6 hours, 12 hours, 18 hours and 24 hours ahead respectively is $54.01 \%$; $49.45 \% ; 47.38 \%$ and $50.83 \%$. In Figure 23, the current speed predictor Model B has the largest percentage of the predicted current speed 6 hours ahead $(\mathrm{Cu}(\mathrm{t}+6))$ is $54.01 \%$ and the predicted results graph patterns fraction follows the pattern graph of the actual current speed, this means that a small portion of data that have a common membership functions. This happens because the 5 membership functions used by division of the Beaufort scale only two categories that have the common that most categories very slow $(0.08 \mathrm{~cm} / \mathrm{s}-5.55 \mathrm{~cm} / \mathrm{s})$ and a fraction $\operatorname{slow}(5.56 \mathrm{~cm} / \mathrm{s}-10.27 \mathrm{~cm} / \mathrm{s})$.

In Model C current speed predictor, percentage of validation results for the prediction of 6 hours, 12 hours, 18 hours and 24 hours ahead respectively is $86.33 \%$; $85.91 \%$; $85.34 \%$ and $86.19 \%$. Graph validation results can be seen in Figure 28-31. In Figure 14, the current speed predictor Model $\mathrm{C}$ has the largest percentage contained in the current speed prediction 6 hours ahead $(\mathrm{Cu}(\mathrm{t}+6))$ is $86.33 \%$ and the predicted results graph patterns current speed 6 hours ahead $(\mathrm{Cu}(\mathrm{t}+6))$ Model $\mathrm{C}$ can largely follows the pattern graph of the actual current speed, this means that most of the data are the same in the membership functions. This happens because the data are most of represented in a 4 membership functions, for category very slow $(0.08 \mathrm{~cm} / \mathrm{s}-9.15 \mathrm{~cm} / \mathrm{s})$, slow $(9.16$ $\mathrm{cm} / \mathrm{s}-20.11 \mathrm{~cm} / \mathrm{s})$, smooth $(20.19 \mathrm{~cm} / \mathrm{s}-41.32 \mathrm{~cm} / \mathrm{s})$ and slight $(41.62 \mathrm{~cm} / \mathrm{s}-146.26 \mathrm{~cm} / \mathrm{s})$.

In this research, predictor Model $\mathrm{C}$ is the best model in the Ternate waters. When compared with previous studies such as studies on maritime weather prediction by using fuzzy logic in the Java Sea Shipping Line Surabaya-Banjarmasin by Aisjah et al, the results research shows that the predicted wave heights of 1 hour and 24 hours ahead to have an accuracy percentage $86.1 \%$ in the Surabaya waters and $71.37 \%$ in Banjarmasin Water respectively, while current speed predictions have an accuracy percentage of $40.61 \%$ for 24 hours ahead. Results of the analysis show that the uses of fuzzy logic Takagi-Sugeno type until the time of this research resulted in a better than prediction accuracy. The percentage of accuracy obtained in this research with previous research is different because of the pattern of waves height and current speed in the Java Sea and the Ternate waters of different. of the waves height pattern is essentially unpredictable and frequently changing erratically while the general pattern of surface sea currents influenced by physical factors and variables such as friction, gravity, motion of earth's rotation, geography continents, sea floor topography and local winds. The combination of various interactions of these factors bring about the presence of sea current that flow all the time and interconnected on a world scale [8].

\section{CONCLUSION}

From this research can be concluded that:

1. Model A predictor uses 7 membership functions for 3 input variables and biggest accuracy percentage in prediction waves height 18 hours ahead is $23,89 \%$ and current speed 24 hours ahead is $44,71 \%$.

2. Model B predictor uses 5 membership functions for 4 input variables and biggest accuracy percentage in

3. Prediction waves height 6 hours ahead is $59,81 \%$ and current speed 6 hours ahead is 54,01\%.

4. Model $\mathrm{C}$ predictor uses 4 membership functions for 3 input variables and biggest accuracy percentage in prediction waves height 6 hours ahead is $91,99 \%$ and current speed 6 hours ahead is $86,33 \%$.

5. To reach accuracy performance $>85 \%$, Model $\mathrm{C}$ predictor is the best predictor in Ternate waters because has biggest percentage to predicts waves height 6 hours ahead is $91,99 \%$ and current speed 6 hours ahead is $86,33 \%$.

6. Membership functions has to suit with the research data to reach high accuracy value.

\section{REFERENCES}

[1] S. Arifin, A. S. Aisjah and H. Fatah, "Analysis of Maritime Weather Charachteristic Based on Result of Land Weather using Fuzzy Logic Prediction in Pasuruan, Probolinggo and Situbondo," in International Conference on Information, Communication Technology and System, Surabaya, 2014.

[2] A. S. Aisjah and S. Arifin, "Aplikasi Sistem Logika Fuzzy pada Peramalan Cuaca Di Indonesia Untuk Mendeteksi Kejadian Anomali Tinggi Gelombang Laut," LPPM Institut Teknologi Sepuluh Nopember, Surabaya, 2010.

[3] A. Zamani, D. Solomatine, A. Azimian and A. Heemink, "Learning from Data for Wind Wave Forecasting," Ocean Engineering, vol. 35, no. 10, pp. 953-962, 2008

[4] A. S. Aisjah and S. Arifin, "Maritime Weather Prediction using Fuzzy Logic in Java Sea," in International Conference On Instrumentation Control and Automation, Bandung, 2011.

[5] G. Sylaios, F. Bouchette, V. A. Tsihrintzis and C. Denamiel, "A Fuzzy Inference System for Wind-Wave Modelling," Ocean Engineering, vol. 38, no. 17-18, p. 1358-1365, 2009.

[6] World Meteorological Organization, Guide to wave and forecasting WMO- No 702, Geneva: Secretariat of The World Meteorological Organization, 1998.

[7] W. Wei, Y. Zhang, G. Wu and M. Tong, "Ultra-short-term /Shortterm Wind Power Continuous Prediction Based on Fuzzy Clustering Analysis", IEEE PES ISGT ASIA 2012 1569613375," in IEEE PES Innovative Smart Grid Technologies, Tianjin, 2012.

[8] M. H. Kazeminezhad, A. Etemad-Shahidi and S. J. Mousavi, "Aplication of Fuzzy Inference System In The Prediction Wave Parameters," Ocean Engineering, vol. 32, no. 14-15, pp. 1709$1725,2005$. 


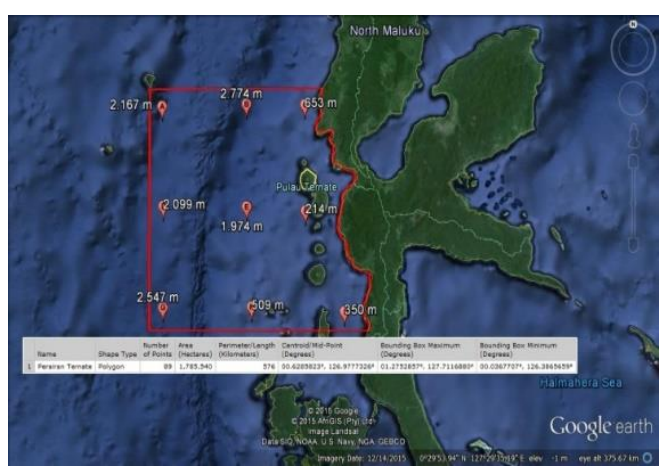

Figure 1. Data collection location (Google Earth)

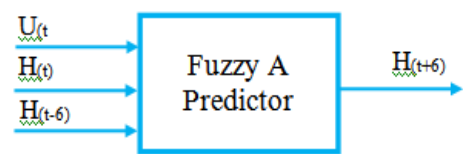

Figure 2. Diagram block of waves height Model A

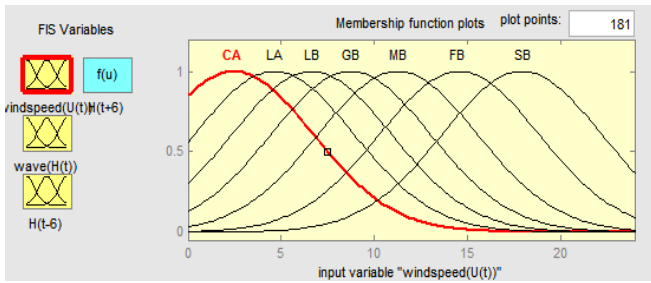

Figure 3. Membership function of wind speed Model A

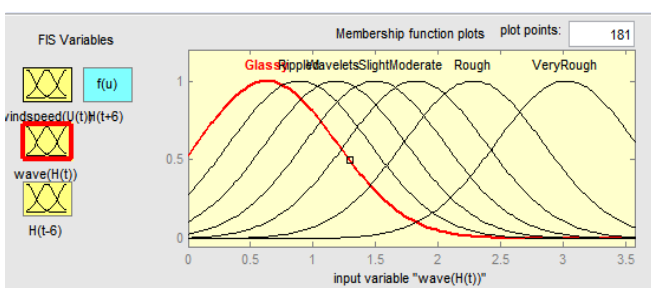

Figure 4. Membership function of wave height Model A

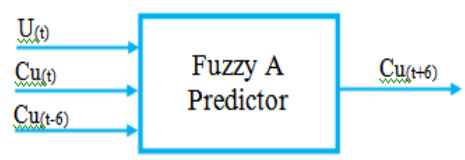

Figure 5. Diagram block of current speed Model A

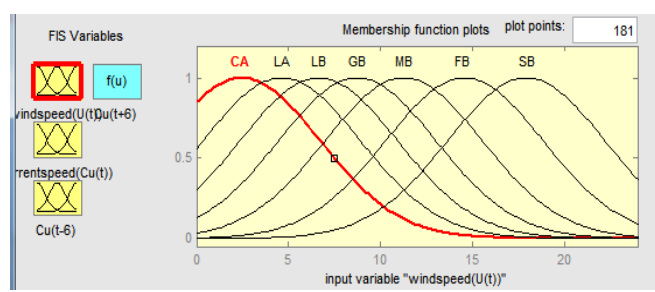

Figure 6. Membership function of wind speed Model A

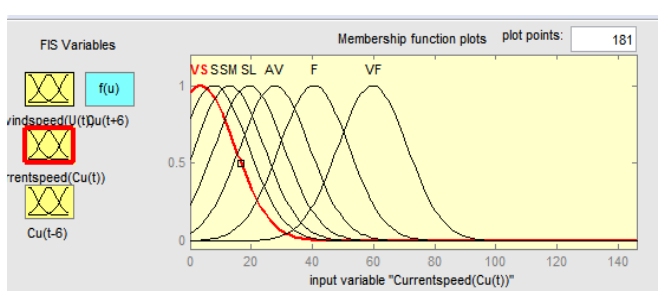

Figure 7. Membership function of current speed Model A

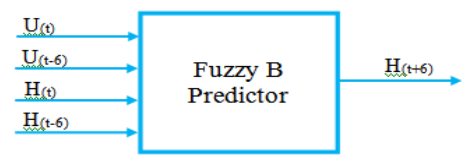

Figure 8. Diagram block of waves height Model B

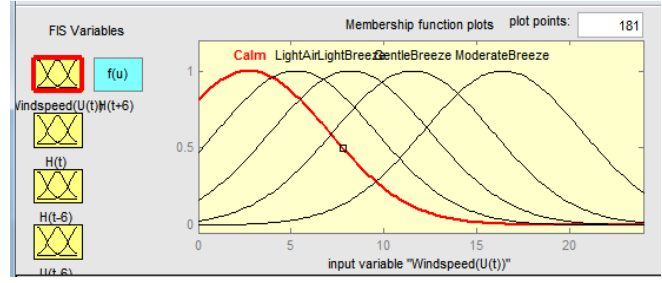

Figure 9. Membership function of wind speed Model B

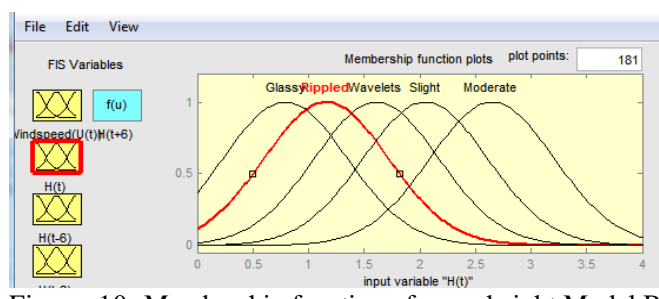

Figure 10. Membership function of wave height Model B

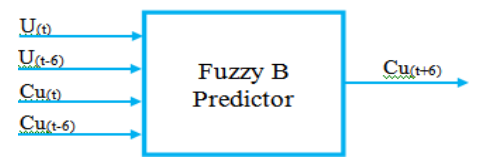

Figure 11. Diagram block of current speed Model B

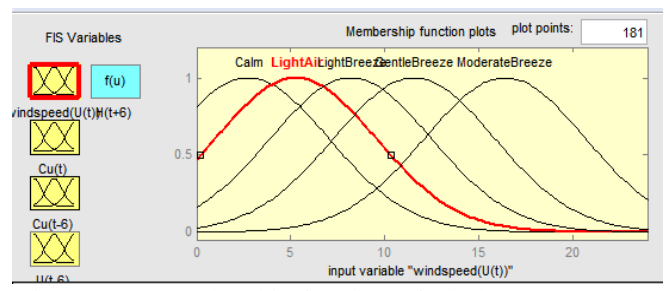

Figure 12. Membership function of wind speed Model B

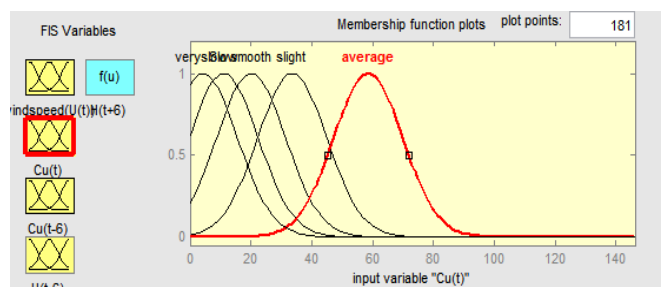

Figure 13. Membership function of current speed Model B

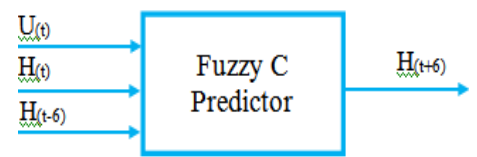

Figure 14. Diagram block of waves height Model C

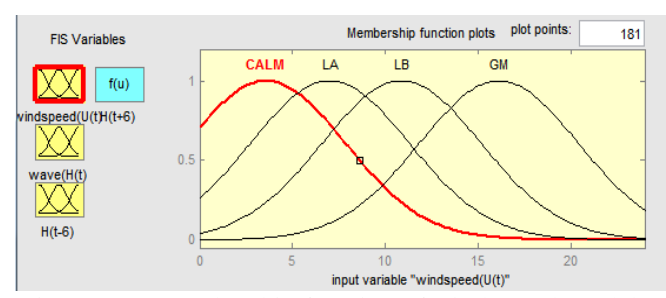

Figure 15. Membership function of wind speed Model C

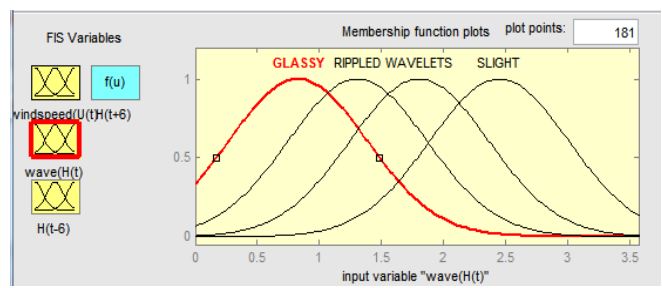

Figure 16. Membership function of wave height Model C 


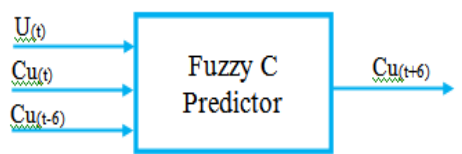

Figure 17. Diagram block of current speed Model C

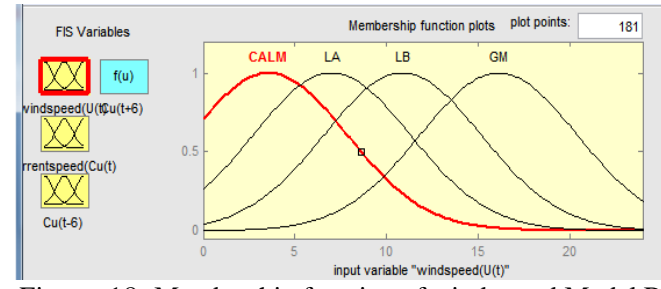

Figure 18. Membership function of wind speed Model B

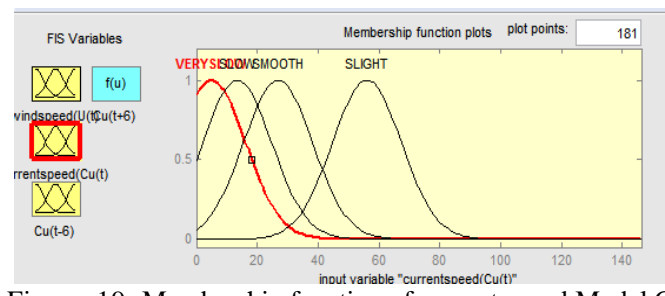

Figure 19. Membership function of current speed Model C

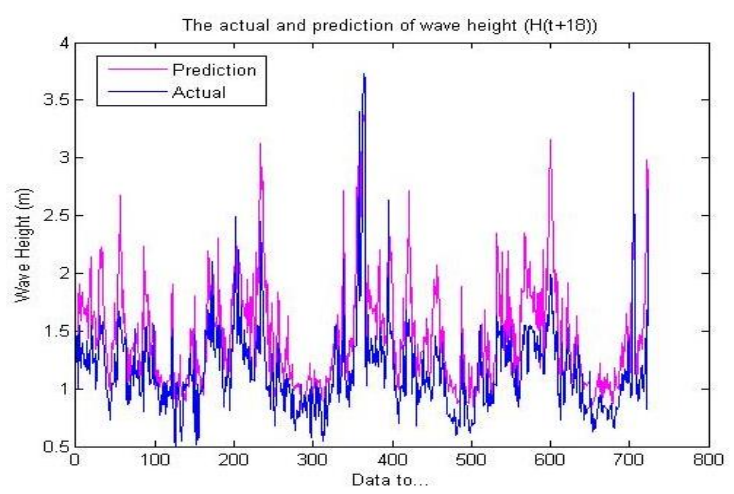

Figure 20. Predicted and Actual Results graph of waves height 18 hours ahead $(\mathrm{H}(\mathrm{t}+18))$ Model A

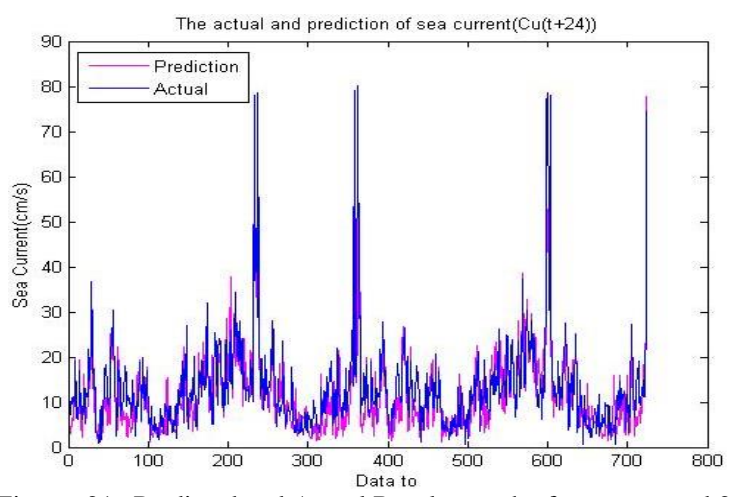

Figure 21. Predicted and Actual Results graph of current speed 24 hours ahead $(\mathrm{H}(\mathrm{t}+24))$ Model A

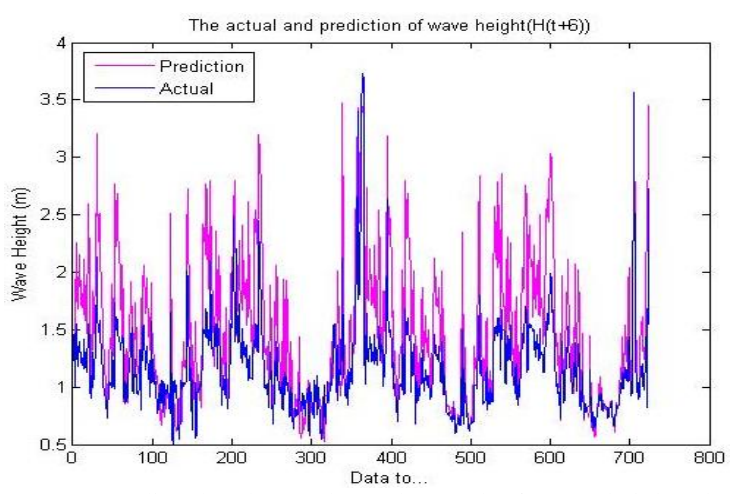

Figure 22. Predicted and Actual Results graph of waves height 6 hours ahead $(\mathrm{H}(\mathrm{t}+6))$ Model $\mathrm{B}$

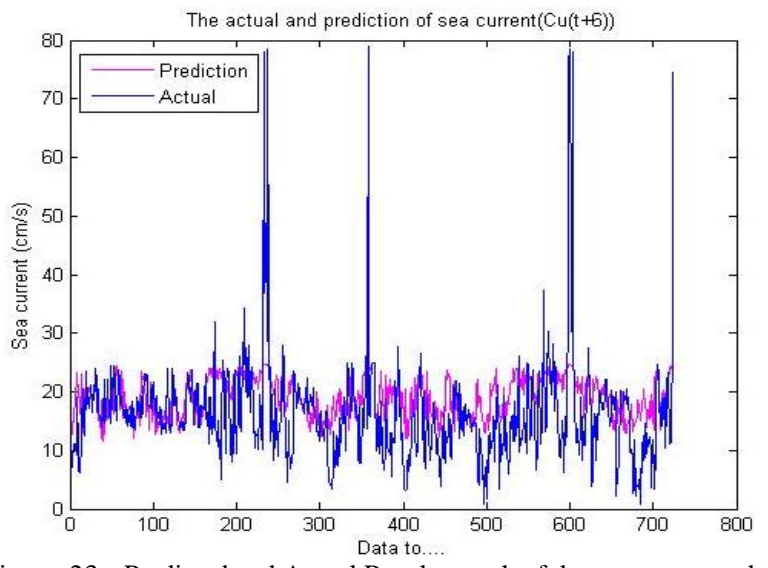

Figure 23. Predicted and Actual Results graph of data current speed 6 hours ahead $(\mathrm{H}(\mathrm{t}+6))$ Model B

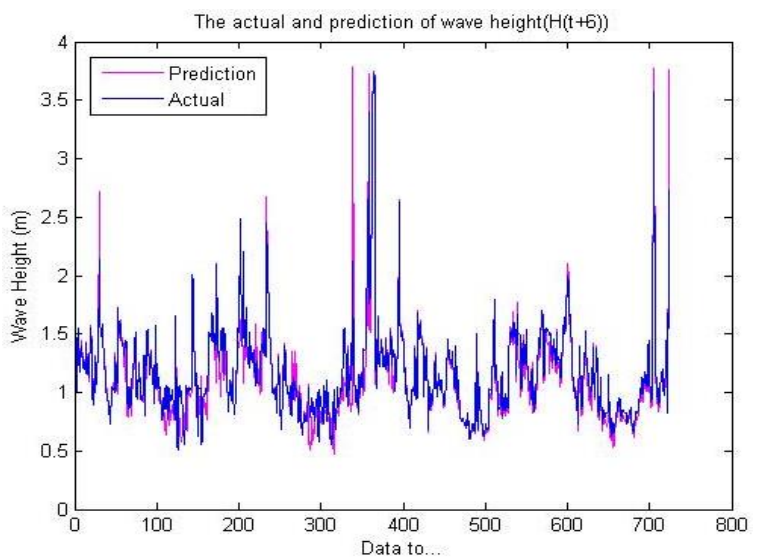

Figure 24. Predicted and Actual Results graph of waves height 6 hours ahead $(\mathrm{H}(\mathrm{t}+6))$ Model $\mathrm{C}$

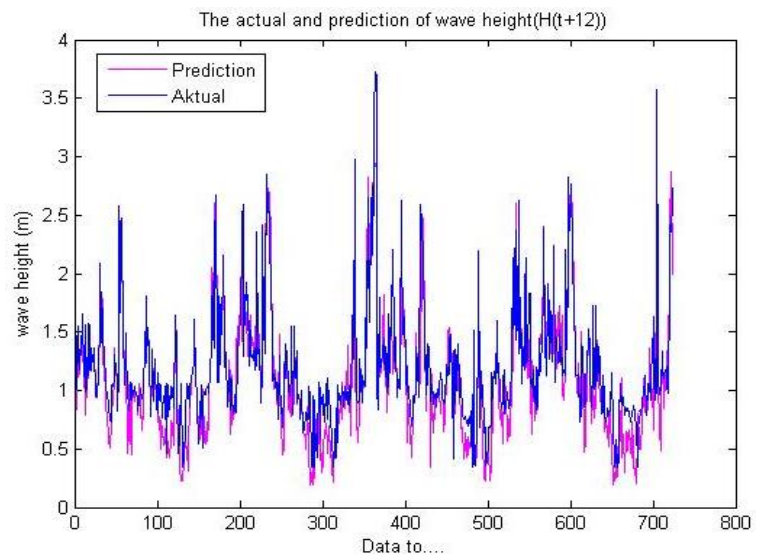

Figure 25. Predicted and Actual Results graph of waves height 12 hours ahead $(\mathrm{H}(\mathrm{t}+12))$ Model $\mathrm{C}$

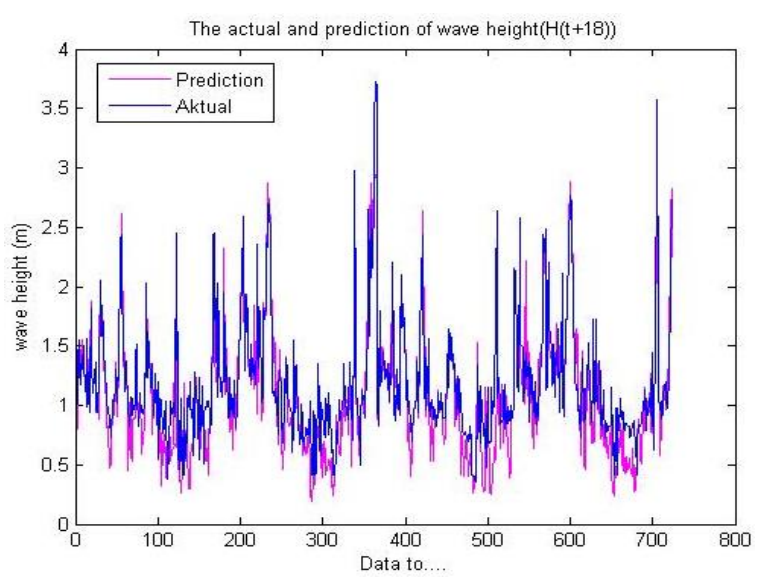

Figure 26. Predicted and Actual Results graph of waves height 18 hours ahead $(\mathrm{H}(\mathrm{t}+18))$ Model $\mathrm{C}$ 


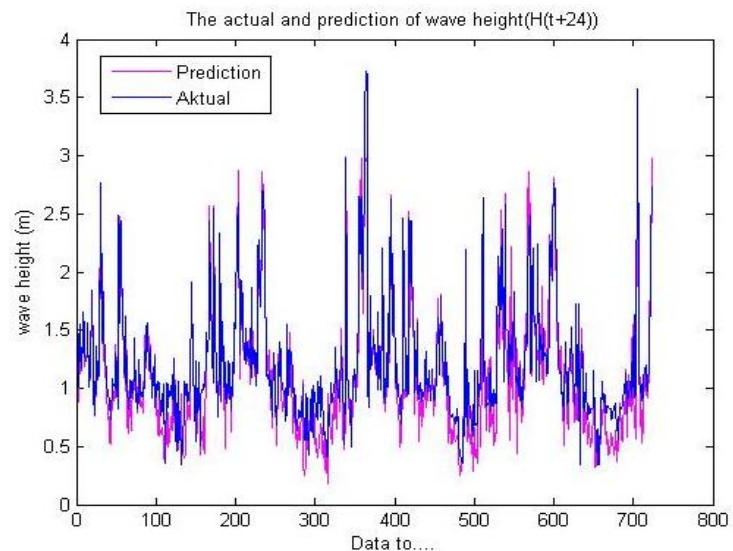

Figure 27. Predicted and Actual Results graph of waves height 24 hours ahead $(\mathrm{H}(\mathrm{t}+24))$ Model C

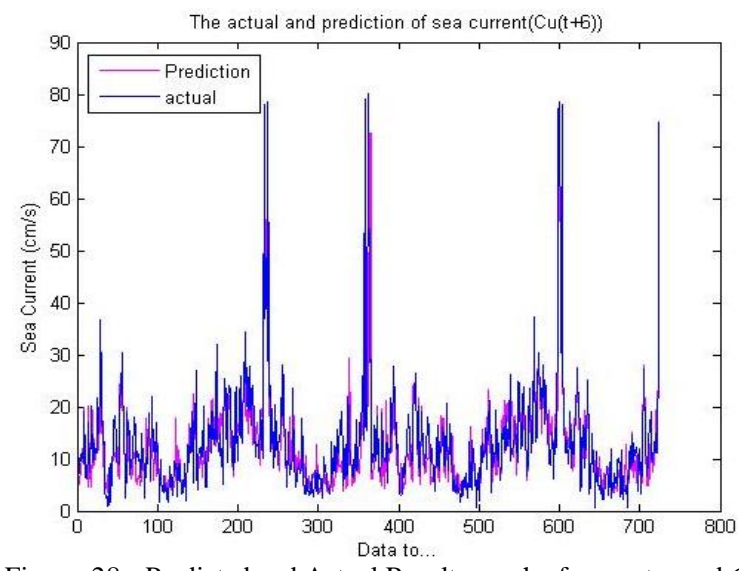

Figure 28. Predicted and Actual Results graph of current speed 6

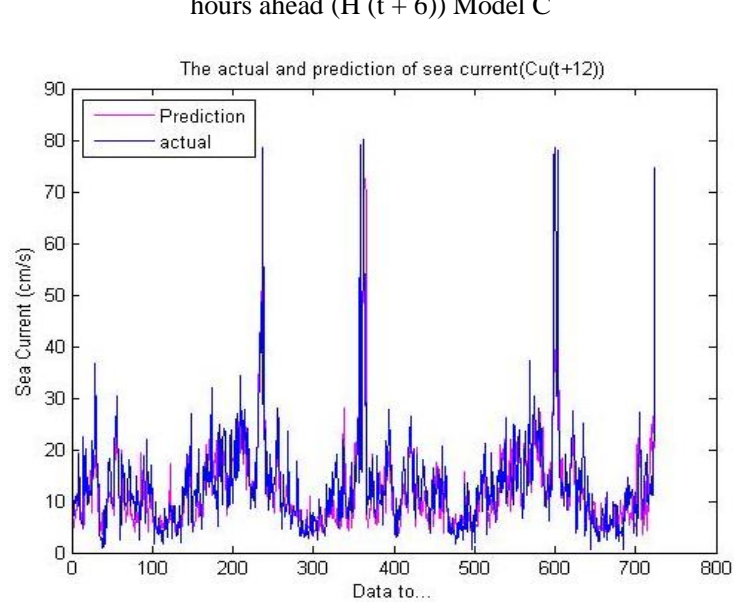

Figure 29. Predicted and Actual Results graph of current speed 12 hours ahead $(\mathrm{H}(\mathrm{t}+12))$ Model C

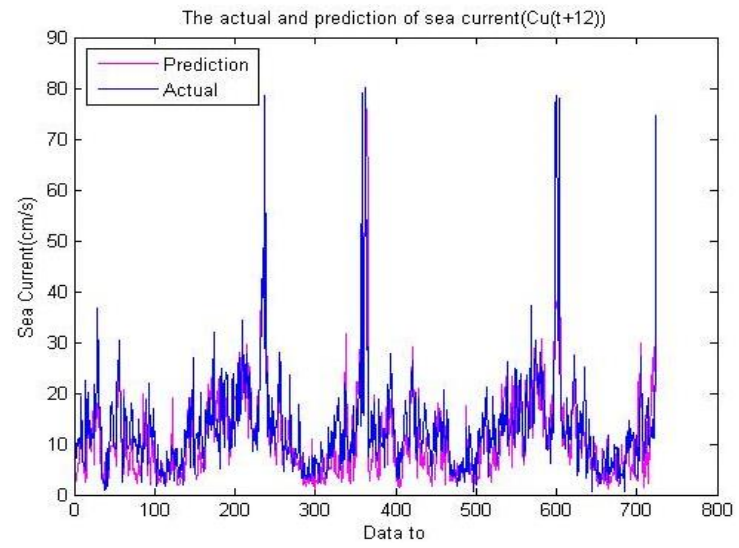

Figure 30. Predicted and Actual Results graph of current speed 18 hours ahead $(\mathrm{H}(\mathrm{t}+18))$ Model $\mathrm{C}$

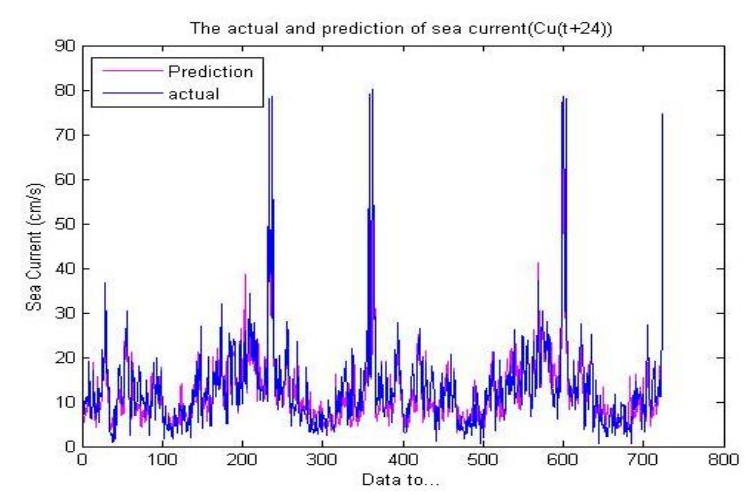

Figure 31. Predicted and Actual Results graph of current speed 24 hours ahead $(\mathrm{H}(\mathrm{t}+24))$ Model C

TABLE 1.

WAVE Height Rule BaSE ALgorithm Model A

\begin{tabular}{|c|c|c|c|c|c|c|}
\hline No & If & $\begin{array}{c}\mathbf{U}(\mathbf{t}) \\
(\mathbf{K n o t})\end{array}$ & $\begin{array}{r}\mathbf{H}(\mathbf{t}) \\
(\mathbf{m})\end{array}$ & $\begin{array}{c}\mathbf{H}(\mathbf{t}-\mathbf{6}) \\
(\mathbf{m})\end{array}$ & Then & $\begin{array}{c}\mathbf{H}(\mathbf{t}+\mathbf{6}) \\
(\mathbf{m})\end{array}$ \\
\hline 1 & If & Calm & Glassy & Glassy & Then & Glassy \\
\hline 2 & If & Light Air & Rippled & Rippled & Then & Rippled \\
\hline 3 & If & $\begin{array}{l}\text { Light } \\
\text { Breeze }\end{array}$ & Smooth & Smooth & Then & Smooth \\
\hline 4 & If & $\begin{array}{l}\text { Gentle } \\
\text { Breeze }\end{array}$ & Slight & Slight & Then & Slight \\
\hline 5 & If & $\begin{array}{l}\text { Moderate } \\
\text { Breeze }\end{array}$ & Moderate & Moderate & Then & Moderate \\
\hline 6 & If & Calm & Rought & Rought & Then & Rought \\
\hline 7 & If & Calm & $\begin{array}{l}\text { Very } \\
\text { Rought }\end{array}$ & $\begin{array}{l}\text { Very } \\
\text { Rought }\end{array}$ & Then & $\begin{array}{l}\text { Very } \\
\text { Rought }\end{array}$ \\
\hline 8 & If & Calm & Rippled & Rippled & Then & Rippled \\
\hline 9 & If & Calm & Smooth & Smooth & Then & Smooth \\
\hline 10 & If & Calm & Slight & Slight & Then & Slight \\
\hline 11 & If & Calm & Moderate & Moderate & Then & Moderate \\
\hline 12 & If & Calm & Rought & Rought & Then & Rought \\
\hline 13 & If & Calm & $\begin{array}{l}\text { Very } \\
\text { Rought }\end{array}$ & $\begin{array}{l}\text { Very } \\
\text { Rought }\end{array}$ & Then & $\begin{array}{l}\text { Very } \\
\text { Rought }\end{array}$ \\
\hline 14 & If & Light Air & Glassy & Glassy & Then & Glassy \\
\hline 15 & If & Light Air & Smooth & Smooth & Then & Smooth \\
\hline 16 & If & Light Air & Slight & Slight & Then & Slight \\
\hline 17 & If & Light Air & Moderate & Moderate & Then & Moderate \\
\hline 18 & If & Light Air & Rought & Rought & Then & Rought \\
\hline 19 & If & Light Air & $\begin{array}{l}\text { Very } \\
\text { rought }\end{array}$ & $\begin{array}{l}\text { Very } \\
\text { rought }\end{array}$ & Then & $\begin{array}{l}\text { Very } \\
\text { rought }\end{array}$ \\
\hline 20 & If & $\begin{array}{l}\text { Light } \\
\text { Breeze }\end{array}$ & Glassy & Glassy & Then & Glassy \\
\hline 21 & If & $\begin{array}{l}\text { Light } \\
\text { Breeze }\end{array}$ & Rippled & Rippled & Then & Rippled \\
\hline 22 & If & $\begin{array}{l}\text { Light } \\
\text { Breeze }\end{array}$ & Slight & Slight & Then & Slight \\
\hline 23 & If & $\begin{array}{l}\text { Light } \\
\text { Breeze }\end{array}$ & Moderate & Moderate & Then & Moderate \\
\hline 24 & If & $\begin{array}{l}\text { Light } \\
\text { Breeze }\end{array}$ & Rought & Rought & Then & Rought \\
\hline 25 & If & $\begin{array}{l}\text { Light } \\
\text { Breeze }\end{array}$ & $\begin{array}{l}\text { Very } \\
\text { Rought }\end{array}$ & $\begin{array}{l}\text { Very } \\
\text { Rought }\end{array}$ & Then & $\begin{array}{l}\text { Very } \\
\text { Rought }\end{array}$ \\
\hline 26 & If & $\begin{array}{l}\text { Gentle } \\
\text { Breeze }\end{array}$ & Glassy & Glassy & Then & Glassy \\
\hline 27 & If & $\begin{array}{l}\text { Gentle } \\
\text { Breeze }\end{array}$ & Rippled & Rippled & Then & Rippled \\
\hline 28 & If & $\begin{array}{l}\text { Gentle } \\
\text { Breeze }\end{array}$ & Smooth & Smooth & Then & Smooth \\
\hline
\end{tabular}




\begin{tabular}{|c|c|c|c|c|c|c|}
\hline 29 & If & $\begin{array}{l}\text { Gentle } \\
\text { Breeze }\end{array}$ & Moderate & Moderate & Then & Moderate \\
\hline 30 & If & $\begin{array}{l}\text { Gentle } \\
\text { Breeze }\end{array}$ & Rought & Rought & Then & Rought \\
\hline 31 & If & $\begin{array}{l}\text { Gentle } \\
\text { Breeze }\end{array}$ & $\begin{array}{l}\text { Very } \\
\text { Rought }\end{array}$ & $\begin{array}{l}\text { Very } \\
\text { Rought }\end{array}$ & Then & $\begin{array}{l}\text { Very } \\
\text { Rought }\end{array}$ \\
\hline 32 & If & $\begin{array}{l}\text { Moderate } \\
\text { Breeze }\end{array}$ & Glassy & Glassy & Then & Glassy \\
\hline 33 & If & $\begin{array}{l}\text { Moderate } \\
\text { Breeze }\end{array}$ & Rippled & Rippled & Then & Rippled \\
\hline 34 & If & $\begin{array}{l}\text { Moderate } \\
\text { Breeze }\end{array}$ & Smooth & Smooth & Then & Smooth \\
\hline 35 & If & $\begin{array}{l}\text { Moderate } \\
\text { Breeze }\end{array}$ & Slight & Slight & Then & Slight \\
\hline 36 & If & $\begin{array}{l}\text { Moderate } \\
\text { Breeze }\end{array}$ & Rought & Rought & Then & Rought \\
\hline 37 & If & $\begin{array}{l}\text { Moderate } \\
\text { Breeze }\end{array}$ & $\begin{array}{l}\text { Very } \\
\text { Rought }\end{array}$ & $\begin{array}{l}\text { Very } \\
\text { Rought }\end{array}$ & Then & $\begin{array}{l}\text { Very } \\
\text { Rought }\end{array}$ \\
\hline 38 & If & $\begin{array}{l}\text { Fresh } \\
\text { Breeze }\end{array}$ & Glassy & Glassy & Then & Glassy \\
\hline 39 & If & $\begin{array}{l}\text { Fresh } \\
\text { Breeze }\end{array}$ & Rippled & Rippled & Then & Rippled \\
\hline 40 & If & $\begin{array}{l}\text { Fresh } \\
\text { Breeze }\end{array}$ & Smooth & Smooth & Then & Smooth \\
\hline 41 & If & $\begin{array}{l}\text { Fresh } \\
\text { Breeze }\end{array}$ & Slight & Slight & Then & Slight \\
\hline 42 & If & $\begin{array}{l}\text { Fresh } \\
\text { Breeze }\end{array}$ & Moderate & Moderate & Then & Moderate \\
\hline 43 & If & $\begin{array}{l}\text { Fresh } \\
\text { Breeze }\end{array}$ & $\begin{array}{l}\text { Very } \\
\text { Rought }\end{array}$ & $\begin{array}{l}\text { Very } \\
\text { Rought }\end{array}$ & Then & $\begin{array}{l}\text { Very } \\
\text { Rought }\end{array}$ \\
\hline 44 & If & $\begin{array}{l}\text { Strong } \\
\text { Breeze }\end{array}$ & Glassy & Glassy & Then & Glassy \\
\hline 45 & If & $\begin{array}{l}\text { Strong } \\
\text { Breeze }\end{array}$ & Rippled & Rippled & Then & Rippled \\
\hline 46 & If & $\begin{array}{l}\text { Strong } \\
\text { Breeze }\end{array}$ & Smooth & Smooth & Then & Smooth \\
\hline 47 & If & $\begin{array}{l}\text { Strong } \\
\text { Breeze }\end{array}$ & Slight & Slight & Then & Slight \\
\hline 48 & If & $\begin{array}{l}\text { Strong } \\
\text { Breeze }\end{array}$ & Moderate & Moderate & Then & Moderate \\
\hline 49 & If & $\begin{array}{l}\text { Strong } \\
\text { Breeze }\end{array}$ & Rought & Rought & Then & Rought \\
\hline
\end{tabular}

TABLE 2.

Current SPeEd Rule BASE Algorithm Model A

\begin{tabular}{|c|c|c|c|c|c|c|}
\hline No & If & $\begin{array}{c}\mathbf{U}(\mathbf{t}) \\
(\text { Knot) }\end{array}$ & $\begin{array}{c}\mathrm{Cu}(\mathrm{t}) \\
(\mathrm{cm} / \mathrm{s})\end{array}$ & $\begin{array}{c}\mathrm{Cu}(\mathrm{t}-6) \\
(\mathrm{cm} / \mathrm{s})\end{array}$ & Then & $\begin{array}{c}\mathrm{Cu}(\mathrm{t}+6) \\
(\mathrm{cm} / \mathrm{s})\end{array}$ \\
\hline 1 & If & Calm & $\begin{array}{l}\text { Very } \\
\text { slow }\end{array}$ & $\begin{array}{l}\text { Very } \\
\text { slow }\end{array}$ & Then & $\begin{array}{l}\text { Very } \\
\text { slow }\end{array}$ \\
\hline 2 & If & Light Air & Slow & Slow & Then & Slow \\
\hline 3 & If & $\begin{array}{l}\text { Light } \\
\text { Breeze }\end{array}$ & Smooth & Smooth & Then & Smooth \\
\hline 4 & If & $\begin{array}{l}\text { Gentle } \\
\text { Breeze }\end{array}$ & Slight & Slight & Then & Slight \\
\hline 5 & If & $\begin{array}{l}\text { Moderate } \\
\text { Breeze }\end{array}$ & Average & Average & Then & Average \\
\hline 6 & If & Calm & Fast & Fast & Then & Fast \\
\hline 7 & If & Calm & $\begin{array}{l}\text { Very } \\
\text { Fast }\end{array}$ & $\begin{array}{l}\text { Very } \\
\text { Fast }\end{array}$ & Then & $\begin{array}{l}\text { Very } \\
\text { Fast }\end{array}$ \\
\hline 8 & If & Calm & Slow & Slow & Then & Slow \\
\hline 9 & If & Calm & Smooth & Smooth & Then & Smooth \\
\hline 10 & If & Calm & Slight & Slight & Then & Slight \\
\hline 11 & If & Calm & Average & Average & Then & Average \\
\hline 12 & If & Calm & Fast & Fast & Then & Fast \\
\hline 13 & If & Calm & Very & Very & Then & Very \\
\hline
\end{tabular}

\begin{tabular}{|c|c|c|c|c|c|c|}
\hline & & & Fast & Fast & & Fast \\
\hline 14 & If & Light Air & $\begin{array}{l}\text { Very } \\
\text { slow }\end{array}$ & $\begin{array}{l}\text { Very } \\
\text { slow }\end{array}$ & Then & $\begin{array}{l}\text { Very } \\
\text { slow }\end{array}$ \\
\hline 15 & If & Light Air & Smooth & Smooth & Then & Smooth \\
\hline 16 & If & Light Air & Slight & Slight & Then & Slight \\
\hline 17 & If & Light Air & Average & Average & Then & Average \\
\hline 18 & If & Light Air & Fast & Fast & Then & Fast \\
\hline 19 & If & Light Air & $\begin{array}{l}\text { Very } \\
\text { Fast }\end{array}$ & $\begin{array}{l}\text { Very } \\
\text { Fast }\end{array}$ & Then & $\begin{array}{l}\text { Very } \\
\text { Fast }\end{array}$ \\
\hline 20 & If & $\begin{array}{l}\text { Light } \\
\text { Breeze }\end{array}$ & $\begin{array}{l}\text { Very } \\
\text { slow }\end{array}$ & $\begin{array}{l}\text { Very } \\
\text { slow }\end{array}$ & Then & $\begin{array}{l}\text { Very } \\
\text { slow }\end{array}$ \\
\hline 21 & If & $\begin{array}{l}\text { Light } \\
\text { Breeze }\end{array}$ & Slow & Slow & Then & Slow \\
\hline 22 & If & $\begin{array}{l}\text { Light } \\
\text { Breeze }\end{array}$ & Slight & Slight & Then & Slight \\
\hline 23 & If & $\begin{array}{l}\text { Light } \\
\text { Breeze }\end{array}$ & Average & Average & Then & Average \\
\hline 24 & If & $\begin{array}{l}\text { Light } \\
\text { Breeze }\end{array}$ & Fast & Fast & Then & Fast \\
\hline 25 & If & $\begin{array}{l}\text { Light } \\
\text { Breeze }\end{array}$ & $\begin{array}{l}\text { Very } \\
\text { Fast }\end{array}$ & $\begin{array}{l}\text { Very } \\
\text { Fast }\end{array}$ & Then & $\begin{array}{l}\text { Very } \\
\text { Fast }\end{array}$ \\
\hline 26 & If & $\begin{array}{l}\text { Gentle } \\
\text { Breeze }\end{array}$ & $\begin{array}{l}\text { Very } \\
\text { slow }\end{array}$ & $\begin{array}{l}\text { Very } \\
\text { slow }\end{array}$ & Then & $\begin{array}{l}\text { Very } \\
\text { slow }\end{array}$ \\
\hline 27 & If & $\begin{array}{l}\text { Gentle } \\
\text { Breeze }\end{array}$ & Slow & Slow & Then & Slow \\
\hline 28 & If & $\begin{array}{l}\text { Gentle } \\
\text { Breeze }\end{array}$ & Smooth & Smooth & Then & Smooth \\
\hline 29 & If & $\begin{array}{l}\text { Gentle } \\
\text { Breeze }\end{array}$ & Average & Average & Then & Average \\
\hline 30 & If & $\begin{array}{l}\text { Gentle } \\
\text { Breeze }\end{array}$ & Fast & Fast & Then & Fast \\
\hline 31 & If & $\begin{array}{l}\text { Gentle } \\
\text { Breeze }\end{array}$ & $\begin{array}{l}\text { Very } \\
\text { Fast }\end{array}$ & $\begin{array}{l}\text { Very } \\
\text { Fast }\end{array}$ & Then & $\begin{array}{l}\text { Very } \\
\text { Fast }\end{array}$ \\
\hline 32 & If & $\begin{array}{l}\text { Moderate } \\
\text { Breeze }\end{array}$ & $\begin{array}{l}\text { Very } \\
\text { slow }\end{array}$ & $\begin{array}{l}\text { Very } \\
\text { slow }\end{array}$ & Then & $\begin{array}{l}\text { Very } \\
\text { slow }\end{array}$ \\
\hline 33 & If & $\begin{array}{l}\text { Moderate } \\
\text { Breeze }\end{array}$ & Slow & Slow & Then & Slow \\
\hline 34 & If & $\begin{array}{l}\text { Moderate } \\
\text { Breeze }\end{array}$ & Smooth & Smooth & Then & Smooth \\
\hline 35 & If & $\begin{array}{l}\text { Moderate } \\
\text { Breeze }\end{array}$ & Slight & Slight & Then & Slight \\
\hline 36 & If & $\begin{array}{l}\text { Moderate } \\
\text { Breeze }\end{array}$ & Fast & Fast & Then & Fast \\
\hline 37 & If & $\begin{array}{l}\text { Moderate } \\
\text { Breeze }\end{array}$ & $\begin{array}{l}\text { Very } \\
\text { Fast }\end{array}$ & $\begin{array}{l}\text { Very } \\
\text { Fast }\end{array}$ & Then & $\begin{array}{l}\text { Very } \\
\text { Fast }\end{array}$ \\
\hline 38 & If & $\begin{array}{l}\text { Fresh } \\
\text { Breeze }\end{array}$ & $\begin{array}{l}\text { Very } \\
\text { slow }\end{array}$ & $\begin{array}{l}\text { Very } \\
\text { slow }\end{array}$ & Then & $\begin{array}{l}\text { Very } \\
\text { slow }\end{array}$ \\
\hline 39 & If & $\begin{array}{l}\text { Fresh } \\
\text { Breeze }\end{array}$ & Slow & Slow & Then & Slow \\
\hline 40 & If & $\begin{array}{l}\text { Fresh } \\
\text { Breeze }\end{array}$ & Smooth & Smooth & Then & Smooth \\
\hline 41 & If & $\begin{array}{l}\text { Fresh } \\
\text { Breeze }\end{array}$ & Slight & Slight & Then & Slight \\
\hline 42 & If & $\begin{array}{l}\text { Fresh } \\
\text { Breeze }\end{array}$ & Average & Average & Then & Average \\
\hline 43 & If & $\begin{array}{l}\text { Fresh } \\
\text { Breeze }\end{array}$ & $\begin{array}{l}\text { Very } \\
\text { Fast }\end{array}$ & $\begin{array}{l}\text { Very } \\
\text { Fast }\end{array}$ & Then & $\begin{array}{l}\text { Very } \\
\text { Fast }\end{array}$ \\
\hline 44 & If & $\begin{array}{l}\text { Strong } \\
\text { Breeze }\end{array}$ & $\begin{array}{l}\text { Very } \\
\text { slow }\end{array}$ & $\begin{array}{l}\text { Very } \\
\text { slow }\end{array}$ & Then & $\begin{array}{l}\text { Very } \\
\text { slow }\end{array}$ \\
\hline 45 & If & $\begin{array}{l}\text { Strong } \\
\text { Breeze }\end{array}$ & Slow & Slow & Then & Slow \\
\hline 46 & If & $\begin{array}{l}\text { Strong } \\
\text { Breeze }\end{array}$ & Smooth & Smooth & Then & Smooth \\
\hline 47 & If & $\begin{array}{l}\text { Strong } \\
\text { Breeze }\end{array}$ & Slight & Slight & Then & Slight \\
\hline
\end{tabular}




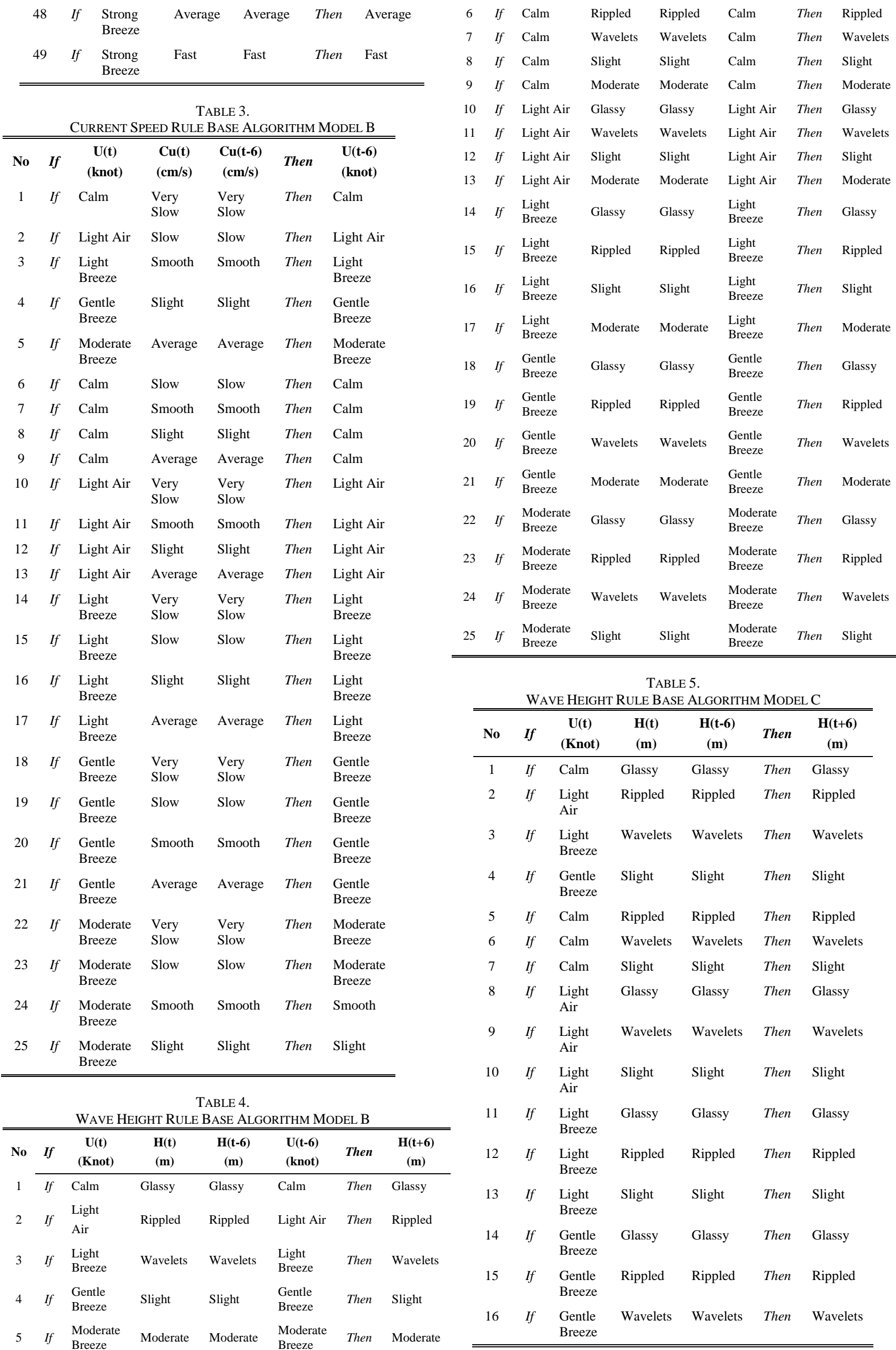


TABLE 6.

CURRENT SPEED RULE BASE ALGORITHM MODEL C

\begin{tabular}{|c|c|c|c|c|c|c|}
\hline No & If & $\begin{array}{c}\mathbf{U}(\mathbf{t}) \\
(\text { Knot) }\end{array}$ & $\begin{array}{l}\mathbf{H}(\mathbf{t}) \\
(\mathbf{m})\end{array}$ & $\begin{array}{c}\mathbf{H}(\mathbf{t}-6) \\
(\mathrm{m})\end{array}$ & Then & $\begin{array}{c}\mathbf{H}(\mathbf{t}+\mathbf{6}) \\
(\mathrm{m})\end{array}$ \\
\hline 1 & If & Calm & $\begin{array}{l}\text { Very } \\
\text { slow }\end{array}$ & $\begin{array}{l}\text { Very } \\
\text { slow }\end{array}$ & Then & $\begin{array}{l}\text { Very } \\
\text { slow }\end{array}$ \\
\hline 2 & If & $\begin{array}{l}\text { Light } \\
\text { Air }\end{array}$ & Slow & Slow & Then & Slow \\
\hline 3 & If & $\begin{array}{l}\text { Light } \\
\text { Breeze }\end{array}$ & Smooth & Smooth & Then & Smooth \\
\hline 4 & If & $\begin{array}{l}\text { Gentle } \\
\text { Breeze }\end{array}$ & Slight & Slight & Then & Slight \\
\hline 5 & If & Calm & Slow & Slow & Then & Slow \\
\hline 6 & If & Calm & Smooth & Smooth & Then & Smooth \\
\hline 7 & If & Calm & Slight & Slight & Then & Slight \\
\hline 8 & If & $\begin{array}{l}\text { Light } \\
\text { Air }\end{array}$ & $\begin{array}{l}\text { Very } \\
\text { slow }\end{array}$ & $\begin{array}{l}\text { Very } \\
\text { slow }\end{array}$ & Then & $\begin{array}{l}\text { Very } \\
\text { slow }\end{array}$ \\
\hline 9 & If & $\begin{array}{l}\text { Light } \\
\text { Air }\end{array}$ & Smooth & Smooth & Then & Smooth \\
\hline 10 & If & $\begin{array}{l}\text { Light } \\
\text { Air }\end{array}$ & Slight & Slight & Then & Slight \\
\hline 11 & If & $\begin{array}{l}\text { Light } \\
\text { Breeze }\end{array}$ & $\begin{array}{l}\text { Very } \\
\text { slow }\end{array}$ & $\begin{array}{l}\text { Very } \\
\text { slow }\end{array}$ & Then & $\begin{array}{l}\text { Very } \\
\text { slow }\end{array}$ \\
\hline 12 & If & $\begin{array}{l}\text { Light } \\
\text { Breeze }\end{array}$ & Slow & Slow & Then & Slow \\
\hline 13 & If & $\begin{array}{l}\text { Light } \\
\text { Breeze }\end{array}$ & Slight & Slight & Then & Slight \\
\hline 14 & If & $\begin{array}{l}\text { Gentle } \\
\text { Breeze }\end{array}$ & $\begin{array}{l}\text { Very } \\
\text { slow }\end{array}$ & $\begin{array}{l}\text { Very } \\
\text { slow }\end{array}$ & Then & $\begin{array}{l}\text { Very } \\
\text { slow }\end{array}$ \\
\hline 15 & If & $\begin{array}{l}\text { Gentle } \\
\text { Breeze }\end{array}$ & Slow & Slow & Then & Slow \\
\hline 16 & If & $\begin{array}{l}\text { Gentle } \\
\text { Breeze }\end{array}$ & Smooth & Smooth & Then & Smooth \\
\hline
\end{tabular}

